\title{
Prevalence and Public Health Implications of the Microbial load ofAbused Naira notes in Dutse metropolis, Jigawa state
}

\author{
${ }^{*}$ Sani N.M., ${ }^{2}$ Baba B. A. ${ }^{2}$ Yahuza S. ${ }^{2}$ Salim F.B., ${ }^{2}$ Yaro S.A., ${ }^{2}$ Mujahid N.S and \\ ${ }^{3}$ Ayuba Daniel Kwada \\ ${ }^{* 1}$ Department of Microbiology and Biotechnology, Federal University Dutse PMB 7156, Ibrahim Aliyu Bye- \\ Pass Dutse, Jigawa State - Nigeria \\ 2, Department of Microbiology and Biotechnology, Federal University Dutse PMB 7156, Ibrahim Aliyu Bye- \\ Pass Dutse, Jigawa State - Nigeria \\ ${ }^{3}$ Department of Environmental Sciences, Federal University Dutse PMB 7156, Ibrahim Aliyu Bye-Pass Dutse, \\ Jigawa State - Nigeria
}

\begin{abstract}
Naira notes could be one of the most potential vehicles to transmit infection between people. This study looked at the prevalence and public health implications of the microbial load of abused naira notes in Dutse metropolis, Jigawa state Nigeria. Swab samples from all denominations of the Nigerian currency notes (\$5- 1000) were collected from volunteers, “okada” riders (commercial motor cyclists), beggars, telephone card sellers, shop keepers and traders, butchers, restaurant owners, "suya" (roasted meat), gas meat sellers and other individuals were analyzed. A total of 80 samples were used and percentages of occurrence of each bacterial and fungal isolates were observed. The total percentage occurrence of the bacterial isolates observed indicated thatStaphylococcus spp.had the highestoccurrence of 30.2\%and Bacillus spp with 26.5\% followed by Staphylococcus aureus withthe lowest percentage of $16.3 \%$. The total percentage occurrence of the fungal isolates observed was inRhizopussppwith the highest occurrence of $66.5 \%$ and Aspergillus spp. with $52.8 \%$ respectively, which wasfollowed by the Penicillium spp with the lowest occurrence of 7.6\%.It was also observed that higher denominations were found to be more contaminated than lower denominations. The study therefore suggests that Nigerian naira that is commonly contaminated with harmful microorganisms can be a source of danger to the general public as it could cause enteric diseases, respiratory tract and skin infections. Therefore, care should be taken when handling money and during preparation and handling of food to avoid cross contamination.
\end{abstract}

Keywords: Prevalence, Public Health, Naira notes, Bacteria, Contamination, Diseases, Infection, Cross contamination

\section{Introduction}

Paper money was introduced into Nigeria in 1945 and since then several changes have been made to different denominations used as legal tender. Naira and kobo are official currency of the federal republic of Nigeria. The naira was introduced on January $1^{\text {st }}, 1973$ when the country declaimed its monetary system and substituted the naira for the Nigerian pound which was divided into shillings (Central Bank of Nigeria, 2006). Naira notes are printed by the Nigerian Security Printing and Minting Company (NSPMC) and denominated in value from $\$ 5$ to $\$ 1000$.

The naira note is issued and regulated by the Central Bank of Nigeria (CBN). According to CBN, the expected lifespan of the naira note is 24 month but the mishandling reduces this to less than 6 months. The abused naira note denotes the currency, which had been fairly long (not more than 24 months) in circulation, mishandled, structurally disfigured, literally mutilated and for most of the time they are dirty. Incidentally, abused naira noteswere reported as vehicles of bacterial, mould and other parasitic infections and agents of cross contamination (Jolaoso, 1981: Awodi et al., 2001:, Itoda, 2001). Studies from other parts of the world have also shown that bank notes revealed the presence of high load of germs, which could cause tuberculosis, meningitis, pneumonia, tonsilitis, peptic ulcer, genital tract infection, gastro-intestinal tract infection and lung diseases(Shukla, 1980; Oyler et al., 1996, Pachter et al., 1997, Havas 2000). Contact with contaminated currency notes could also cause diarrhoea and urinary tract infections besides skin burns and septicaemic infections. (Kawo, et al., 2009).Paper money is widely exchanged for goods and services in countries worldwide (Uneke and Ogbu 2007). Naira notes are widely exchanged for goods and services, it is used for every type of commerce from buying telephone cards to paying a bus fare, to sex trafficking and drug deals. All these forms of trade are hard on the currency with lower denomination notes being exchanged many times among individuals than higher denomination notes a classic characteristic of human parasite and bacterial agent in the 
evolution of route for transmission to susceptible host. The environment plays a critical role in transmission to recovery of many pathogenic microorganisms (Dow Jones News, 1998; Food Science Australia, 2000).

Although paper money is impregnated with disinfectant to inhibit microorganisms, however, pathogens have been isolated from currency notes and coins (Talaro, 2005). Research has shown that currency paper provide a large surface area as breeding ground for pathogenic microorganisms. Money on which pathogenic microorganism can survive represent an often overlooked reservoir of enteric diseases (Michaels, 2002). But recent studies from different parts of the world have revealed that currency either as coins or paper have high rate of microbial contamination (Goktas and Oktav, 1992).

Scientific information on the contamination of money by microbial agents is lacking in most developing countries, especially in sub-Saharan Africa which includes Nigeria. This dearth of information have contributed to the absence of public health policies or legislation on currency handling and circulation in those countries that may have fostered a high level of public awareness about the potential of currency contamination by microorganisms (Dow Jones News 1998; Michaels 2002; Pope et al., 2002). In the united states, a whole division of Department of treasury deals with what is termed "Mutilated currency" and the Department website boast many examples of beleaguered, burned and water damaged money (Siddique, 2003).

\section{Materials and Methods}

\section{Study Area}

The study was carried out at the microbiology laboratory of Federal university, Dutse, Jigawa state, Nigeria.

\section{Study population}

A total of 80 samples of naira notes were collected from eight different sites within the study area, where 10 samples of each denomination were collected ( $\$ 5, \$ 10, \$ 20, \$ 50, \aleph 100, \$ 200, \aleph 500, \$ 1000$ ).

\section{Sample collection}

The samples were collected from bus conductors, taxi drivers, traders, business operators, food sellers, butchers, telephone card sellers, beggars and other individuals. Samples were collected aseptically using sterile leather bags and disposable sterile hand gloves. Samples collected were taken immediately into the laboratory foranalysis of the microorganisms (Kawo et al., 2009).

\section{Sample Preparation and Inoculation}

The working bench and environment were disinfectedusing $70 \%$ ethanol. Sterile wet swab sticks were used to roll on the surfaces of the notes. The swab of each sample was dipped in a test tube containing $10 \mathrm{ml}$ distilled water and the swab (cotton wool) was removed from the sticks with the aid of a sterile forcep into the distilled water and was shaken vigorously to dislodge the swabbed content into the solution. The swab was then removed after pressing it several times against the wall of the test tube using the forcep. The solution was then homogenized and serial dilution from $10^{-1}$ to $10^{-5}$ was made.

A $1.0 \mathrm{ml}$ aliquot of the $10^{-3}$ serially diluted sample was inoculated onto MacConkey agar and Nutrient agar (bacteria) and Potato dextrose agar (fungi). The inoculated plates were incubated in an inverted position at 35 to $37^{\circ} \mathrm{C}$ for $24 \mathrm{~h}$ (bacteria) and fungi (PDA plates) at room temperature for 24 to $72 \mathrm{~h}$.

\section{Isolation of Bacterial and Fungal colonies}

Observed mixed colonies on MacConkey agar and Nutrient agar for the bacterial cultures were subcultured on fresh Nutrient agar by streaking according to Cheesbrough, (2000) and the plates were incubated in an inverted position at $37^{\circ} \mathrm{C}$ for $24 \mathrm{~h}$. The mixed growth of the fungi on PDA were sub-cultured onto fresh potato dextrose agar and incubated for $72 \mathrm{~h}$ at $25^{\circ} \mathrm{C}$ for discrete growth. The discrete colonies on each fresh agar plate were observed and recorded. The cultural, morphological and biochemical characterization was done according to Cheesbrough, (2000).

\section{Sterilization}

All apparatus or materials used for the research were sterilized using an autoclave at $121^{\circ} \mathrm{C}$ for 15 minutes. This was done to avoid contamination during the media preparation as well as the sample processing.

\section{Media Preparation}

All the media used were weighed, prepared and sterilized according to the manufacturer's instruction. 


\section{Gram's staining}

Gram staining technique was employed for the identification of the morphological structure of bacteria and its reaction towards the gram stain (Cheesbrough, 2004). Bacteria are classified into two based on their reaction to gram stain viz: Gram positive and Gram negative bacteria.

\section{Biochemical tests}

After isolating the pure culture of each colony of bacteria using various selective and differential media, the colonies were also subjected to various biochemical tests for the confirmation and identification of particular species of bacteria. While for the fungal isolates, lacto phenolcotton blue was used, and only the hyphae were examined microscopically.

\section{Microbial count}

Colonial growth appearance on the plates, Standard Plate Count and Colony Counter were used respectively to count bacterial and fungal isolates.

\section{Results}

The average microbial (bacteria and fungi) count of different naira denominations at a dilution of $10^{3}$ is shown in table 1 , the bacterial isolates have a total count of $483 \mathrm{Cfu} / \mathrm{ml}$ and the fungal isolates have a total count of $760.5 \mathrm{Cfu} / \mathrm{ml}$. The highest bacterial and fungal counts were found on higher denominations i.e. $\$ 200, \$ 500$, and

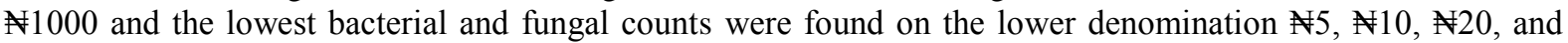
$¥ 50$, while 100 contained the average bacterial and fungal counts respectively.

Table 1: Bacterial and Fungal Counts from Abused Naira Notes

\begin{tabular}{|c|c|c|c|}
\hline Denomination (Naira) & Number examined & $\begin{array}{c}\text { Bacterial count } \\
(\mathrm{cfu} / \mathrm{ml})\end{array}$ & Fungal count (cfu/ml) \\
\hline 100 & 10 & $86.6 \times 10^{3}$ & $122.8 \times 10^{3}$ \\
\hline 500 & 10 & $81.8 \times 10^{3}$ & $131.2 \times 10^{3}$ \\
\hline 200 & 10 & $87.2 \times 10^{3}$ & $107.5 \times 10^{3}$ \\
\hline 100 & 10 & $48.5 \times 10^{3}$ & $102.6 \times 10^{3}$ \\
\hline 50 & 10 & $42.8 \times 10^{3}$ & $90.9 \times 10^{3}$ \\
\hline 20 & 10 & $47.7 \times 10^{3}$ & $116.1 \times 10^{3}$ \\
\hline 10 & 10 & $39.0 \times 10^{3}$ & $35.7 \times 10^{3}$ \\
\hline 5 & 10 & $49.5 \times 10^{3}$ & $53.7 \times 10^{3}$ \\
\hline Total & 80 & $483 \times 10^{3}$ & $760.5 \times 10^{3}$ \\
\hline
\end{tabular}

Table 2shows the percentage occurrence of the bacterial isolates. The total percentage occurrence of the bacterial isolates observed was Staphylococcusspp. having the highest percentage occurrence of $30.2 \%$ and Bacillusspp. with 26.5\% followed by Staphylococcusaureus having the lowest percentage of 16.3\%.

Table 2: Percentage occurrence of bacterial isolates $(\mathrm{n}=80)$

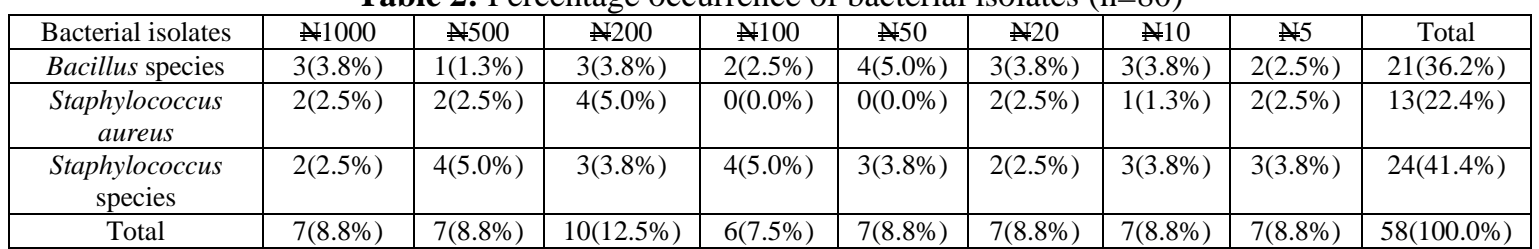

Table 3shows the percentage occurrence of the fungal isolates. The total percentage occurrence of the fungal isolates observed was Rhizopusspp. having the highest percentageoccurrence of $66.5 \%$ and Aspergillusspp. with $52.8 \%$ followed by the Penicilliumspp. having the lowest occurrence of $7.6 \%$ respectively.

Table 3: Percentage occurrence of the fungal isolates $(n=80)$

\begin{tabular}{|c|c|c|c|c|c|c|c|c|c|}
\hline $\begin{array}{c}\text { Fungal } \\
\text { isolates }\end{array}$ & $\mathbb{N} 1000$ & $\mathrm{~N} 500$ & $\mathrm{~N} 200$ & $\mathrm{~N} 100$ & $\mathrm{~N} 50$ & $\mathrm{~N} 20$ & $\mathrm{~N} 10$ & $\mathrm{~N} 5$ & Total \\
\hline $\begin{array}{c}\text { Aspergillus } \\
\text { spp. }\end{array}$ & $5(6.3 \%)$ & $7(8.8 \%)$ & $3(3.8 \%)$ & $6(7.5 \%)$ & $5(6.3 \%)$ & $7(8.8 \%))$ & $6(7.5 \%)$ & $3(3.8 \%)$ & $42(41.6 \%)$ \\
\hline $\begin{array}{c}\text { Penicillium } \\
\text { spp. }\end{array}$ & $1(1.3 \%)$ & $2(2.5 \%)$ & $1(1.3 \%)$ & $0(0.0 \%)$ & $2(2.5 \%)$ & $0(0.0 \%)$ & $0(0.0 \%)$ & $0(0.0 \%)$ & $6(5.9 \%)$ \\
\hline Rhizopus spp. & $7(8.8 \%)$ & $7(8.8 \%)$ & $5(6.3)$ & $9(11.3 \%)$ & $4(5.0 \%)$ & $8(10.0 \%)$ & $5(6.3 \%)$ & $8(10.0 \%)$ & $53(52.5 \%)$ \\
\hline Total & $13(16.3 \%)$ & $16(20.0 \%)$ & $9(11.3 \%)$ & $15(18.8 \%)$ & $11(13.8 \%)$ & $15(18.8 \%)$ & $11(13.8 \%)$ & $11(13.8 \%)$ & $101(100 \%)$ \\
\hline
\end{tabular}

Table 4shows the morphological, and biochemical characteristics of the bacterial isolates, their gram stain reaction behaviour, and their reaction to different biochemical test such as catalase test, coagulase test, 
indole production test, oxidase test and motility test which indicates that they belong to two bacterial genera namely: Bacillusspp., Staphylococcusspp. and Staphylococcusaureus.

Table 4: Morphological and biochemical characteristics of the bacterial isolates

\begin{tabular}{|c|l|l|l|l|ll|l|}
\hline Gram stain reaction & No. & Co & Ca & Mo & In & Ox & Organism \\
\hline Gram positive bacilli & 29 & + & + & - & - & - & Bacillus spp. \\
\hline Gram positive cocci & 13 & + & + & - & - & - & Staphylococcus. Aureus \\
\hline Gram positive cocci & 24 & + & + & - & - & - & Staphylococcus spp. \\
\hline
\end{tabular}

Total number of bacterial isolates $=66$

Key:NO: no. of the organisms isolated, GS: gram's reaction behaviour, CO: coagulase test, CA: Catalase test, MO: Motility test, IN: Indole test and Ox: Oxidase test.

Table 5 Shows the cultural and morphological characteristics of the fungal isolates and their appearance to particular colonies which also indicates that they belong to three fungal genera namely: Rhizopusspp., Aspergillusspp., and Penicillium spp.

Table 5: Cultural and morphological characteristics of the fungal isolates

\begin{tabular}{|c|c|c|c|}
\hline Colony appearance & Morphology & No & Organism \\
\hline $\begin{array}{l}\text { Black fluffy mycelia mat with green } \\
\text { sporangium on furtherincubation. }\end{array}$ & $\begin{array}{l}\text { Septate mycelium with spores radiating from } \\
\text { Conidiophores. }\end{array}$ & 42 & Aspergillusspp. \\
\hline Blue mycelia mat with white outline & $\begin{array}{l}\text { Broom like conidia on } \\
\text { Conidiophores. }\end{array}$ & 06 & Penicilliumspp. \\
\hline $\begin{array}{l}\text { White fluffy mycelia } \\
\text { Mat, with black sporangium on further } \\
\text { incubation }\end{array}$ & $\begin{array}{l}\text { Non septate, cottony myceliumwith } \\
\text { sporangium landed with spore. }\end{array}$ & 53 & Rhizopusspp. \\
\hline
\end{tabular}

Total no. of organisms isolated

101

\section{Discussion}

The findings of this research revealed that both bacteria and fungi were found on the abused naira notes but the fungi were more predominant, this is due to the fact that fungal spores are usually exposed to the atmosphere. However there was no recovery of both bacteria and fungi on the fresh naira mint (control) examined in this research.

Results from Table 1, show that the higher denominations were found to be more contaminated than lower denominations which was contrary to previous findings by Umehet al., (2007), this is probably because Dutse is a central or capital city of Jigawa state and recently the higher denominations are frequently exchanging hands than the lower denominations in Dutse environment, and is so because of the economic imbalance of the nation. Another reason for the high bacterial and fungal counts on the higher denominations could be due to the devaluation of Nigeria's currency coupled with political dispensation where money exchange hands especially during political campaigns, and that most Nigerians have less regard for lower denominations.

That could also justify the fact that coins have completely disappeared and lower denominations are beginning to follow suit as getting a change after transactions in our communities is a big challenge as such, people prefer to use higher denominations nowadays.

The presence of these microorganisms on the notes suggests that the minimum conditions for their presence have been met (Brock et al., 1994). This brings to mind the question: How safe are our naira notes in circulationmicrobiologically? Most moist dirty naira notes provide a good surface and nutrient for bacterial growth. They provide favorable conditions such as substrate acquired from human body and due to handling as well as dust from the environment (Hague, 2003). These microorganisms have come in contact with the money through soil, clothing, food and/or hand of users. Some of these microorganisms are potential disease agents, for example Bacillusspp. and Staphylococcusspp. have been known to be responsible for food intoxication and poisoning (FAO, 1979, Turk et al., 1983; Adesiyun, 1984; Adams and Moss, 1995). While the fungal isolates elaborate mycotoxins in food which are dangerous to human and animal health (Grundy and Grundy, 1974; FAO, 1979). In addition, the findings of this work further suggests that dirty currency could host harmful microorganisms. In a similar study, El-din-El-dars (2005) isolated-twenty five (25) genera of bacteria including the strains of Staphylococcus and Bacillus and a lower proportion of fungal isolates from Egyptian paper notes. Itoda (2001) reported $97.0 \%$ of the samples of the naira notes examined to have been contaminated with bacteria, predominantly Staphylococcusaureus, Escherichiacoli and Corynebacteriumdiphtheriae. In Nigeria, cash transaction is used more frequently than credit cards, traveler's cheques and money orders. The habit of keeping money in bags, pockets, wallets, brassieres, local pots and table covers have been observed among the majority of Nigerians, which may have largely contributed to the high bacterial and fungal loads observed in this study. 


\section{Conclusion}

From this study, it can be deduced that Nigerian currency is commonly contaminated with pathogenic bacteria and fungi, and this contamination may play a significant role in the transmission of infectious diseases. Also the higher denominations were found to be more contaminated than lower denominationswhich is probably because Dutse is a central or capital city of Jigawa state and recently, the higher denominations are more frequently exchanging hands than the lower denominations in Dutse environment this is because due to the economic imbalance in the nation. Also samples collected from butchers ( 11000$)$ and restaurant owners ( $\$ 500)$ were found to have the highest bacterial and fungal counts than other samples collected from the remaining study site.

It can also be concluded that samples collected from butchers, ( $\$ 1000)$, restaurant owners ( $\$ 500)$, and "suya" and gas meat sellers ( 200 ) which are usually the higher denominations had the highest bacterial and fungal contamination than other samples collected from the rest of the study area. This is probably because contaminants like blood from the butcher, residue of fish, house flies, faecesetc. were all found among these denominations.

\section{Recommendations}

From this study the following recommendations were made:

- Currency notes must be handled with caution and great care especially during the preparation and handling of food to avoid contamination.

- Personal hygiene should be increased to reduce risk of infection especially for those that simultaneously handle food and money.

- Food sellers and other volunteers should be educated to avoid possible cross contamination between currency notes and food.

- There should be public awareness due to the fact that currency notes could be a source of infection and dangerous to health.

- Regular microbial testing of currency notes and establishment of method for large scale replacement of contaminated currency should be employed.

- Babies must be prevented from handling currency notes and adults should avoid using saliva during counting of paper currency notes.

- Ministries of health and environment should employ sanitary inspectors to launch a campaign on personal and environmental hygiene including seminars and town hall meetings for petty traders, Okada riders, food handlers, "Suya" sellers, Butchers and the general public on the dangers of contaminated currency notes.

\section{References}

[1]. Adams, M.R. and Moss, M.O. (1995): Food Microbiology. Cambridge University press, United Kingdom.

[2]. Adesiyun, A.A. (1984): Effect of storage and consumer handling on staphylococcal counts of dried beef and dried fish. Journal of Food Protection 47:352-353.

[3]. Awodi NO, Nock I.N. and Aken'Ova I. (2001). Prevalence of Public Health Significance of Parasitic Cysts and Eggs on the Nigerian Currency. The Nigerian Journal of Parasitology. 22:137-142.

[4]. Brock TD, Madigan MT, Mar Tinko JM, Parker J (1994). Biology of Microorganisms. 7th edition. Prentice Hall Englewood Cliffs, New Jersey.

[5]. Central Bank of Nigeria (2011). Nigerian Naira notes. http://www.nigeria=law.org/centralBankofnigeriaDecreehtm. Retrieved on April $6^{\text {th }}, 2011$

[6]. Cheesbrough, M. (2004).District Laboratory Practice in Tropical Countries, part II. K: Cambridge University Press.pp 62-70.

[7]. Cheesbrough, M. (2006).Medical laboratory Manual for Tropical countries 2nd edition. University Press Cambridge Part 1: 200357.

[8]. Dow Jones News (1998). Add to the evils of money the fact it carries many germs. Retrieved may 5, 2011 from http://www.foodcontamination.cal/fsnet/1998/1-1998/fs-0126-98-01.txt.

[9]. El-din-El-dars, H.W. (2005): A preliminary bacterial study of Egyptian paper money. International Journal of Environmental Health Research 15(3):235-246.

[10]. Food and Agricultural Organization (1979).Manuals of food quality control: Food and Nutrition, United Nations, Rome, Italy.

[11]. Food Science Australia (FSA), (2000). Money Handling in Food Operations. Food Safety and hygiene. From http://www.foodscience.cbiroiau/fshbull/fshbull20c.htm.Retrieved May5, 2011.

[12]. Goktas P. and Oktay G. (1992).Bacteriological examination of paper money.Mikrobiyol. Bull., 26:344-348.

[13]. Grundy, F. and Grundy, P. (1974).Community health and social servicesHK Lewis Publishers. London. p. 108.

[14]. Haque Z (2003). Currency Notes as germ carriers. HHP: (www.nation_online.com/20021/22/-n2122208.htm).

[15]. Havas, F. (2000): About the bacteriological state of the Hungarian currency (notes and coins). Magya Allatoryosol Lapja 122(8):501-503.

[16]. Itoda, A. (2001): bacterial load of Nigerian currency (Nairaandkobo). B. Sc thesis, Department of Microbiology, University of Jos, Nigeria Pp1-14.

[17]. Jolaoso, I.I.K. (1981): Dirty Naira notes as vehicles for bacteria and mold infections and as agents of cross contamination. Book of abstracts of the 19th Annual Conference of the Nigerian Society for Microbiology, 1 st $-4^{\text {th }}$ September, 1991 . p24.

[18]. Kawo A.H., Adam M.S., Abdullahi B.A, Sani N.M., (2009). Prevalence and public health implications of microbial load of abused Naira notes. Bayero Journal of Pure and Applied Science. 2(1):52-57.

[19]. Michaels B., (2002). Handling money and serving ready-to-eat food, Food Serv. Technol. 2:1-3. 
[20]. Oyler, J., Darwin, W.D. and Cone, E.J. (1996): Cocaine contamination of United States paper currency. Journal of Analytical Toxicology 20(4):213-216.

[21]. Pachter, B.R., Kozer, L., Pachter, S.A. and Weiner, M. (1997): Dirty money - A bacteriophage investigation of US currency. Infectious Diseases 14(7):574.

[22]. Pope TW, Ender PT, Woelk WK, Koroscil MA and Koroscil TM (2002).Bacterial Contamination of Paper Currency.SouthMedical .Journal. 95:1408-1410.

[23]. Shukla, K.A. (1980): Reservoir of organisms. Indian Journal of Medical Sciences 32(7):168-170.

[24]. Siddique S., (2003). Dirty money: you are carrying more than cash on your wallet. Manila-Philippine Headline News Online.Reported by Vanzi SJ.

[25]. Talaro K. P (2005). Foundation in Microbiology $5^{\text {th }}$ Edition.McGraw-Hill Companies, Inc New York, USA. 407.

[26]. Turk, D.C., Porter, I.A., Deurden, B.I. and Reid, T.H. (1983): A short textbook of medical microbiology. Hodder and Stoughton educational publishers, London. pp84-119.

[27]. Umeh E. U, Juluku J.U. and Ichor T. (2007).Microbial Contamination of Naira (Nigerian Currency) Notes in Circulation.Research Journal of Environmental Sciences. 1(6): 336-339.

[28]. Uneke C.J. and Ogbu O., (2007). Potential for Parasite and Bacteria Transmission by Paper Currency in Nigeria.J. Environ. Health. 69:54-60. 